\title{
Embracing Age
}




\title{
Global Perspectives on Aging
}

\author{
Series editor, Sarah Lamb
}

This series publishes books that will deepen and expand our understanding of age, aging, ageism, and late life in the United States and beyond. The series focuses on anthropology while being open to ethnographically vivid and theoretically rich scholarship in related fields, including sociology, religion, cultural studies, social medicine, medical humanities, gender and sexuality studies, human development, critical and cultural gerontology, and age studies. Books will be aimed at students, scholars, and occasionally the general public.

Jason Danely, Aging and Loss: Mourning and Maturity in Contemporary Japan Parin Dossa and Cati Coe, eds., Transnational Aging and Reconfigurations of Kin Work

Sarah Lamb, ed., Successful Aging as a Contemporary Obsession: Global Perspectives Margaret Morganroth Gullette, Ending Ageism, or How Not to Shoot Old People Ellyn Lem, Gray Matters: Finding Meaning in the Stories of Later Life Michele Ruth Gamburd, Linked Lives: Elder Care, Migration, and Kinship in Sri Lanka

Yohko Tsuji, Through Japanese Eyes: Thirty Years of Studying Aging in America Jessica C. Robbins, Aging Nationally in Contemporary Poland: Memory, Kinship, and Personhood

Rose K. Keimig, Growing Old in a New China: Transitions in Elder Care Anna I. Corwin, Embracing Age: How Catholic Nuns Became Models of Aging Well 


\section{Embracing Age}

\section{How Catholic Nuns Became Models of Aging Well}

ANNA I. CORWIN

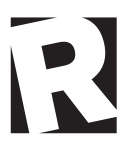

Rutgers University Press

New Brunswick, Camden, and Newark, New Jersey, and London 
Library of Congress Cataloging-in-Publication Data

Names: Corwin, Anna I., author.

Title: Embracing age : how Catholic Nuns became models of aging well / Anna

I. Corwin.

Description: New Brunswick : Rutgers University Press, [202I] | Series:

Global perspectives on aging | Includes bibliographical references and index.

Identifiers: LCCN 2020045576 | ISBN 9781978822276 (paperback) |

ISBN 9781978822283 (hardcover) | ISBN 9781978822290 (epub) |

ISBN 9781978822313 (pdf)

Subjects: LCSH: Aging-Religious aspects-Catholic Church. | Monastic and religious life of women-United States. | School Sisters of Notre Dame. |

Aging-United States. | Nuns-Religious life.

Classification: LCC BV $4580 . C_{585} 2021$ | DDC 271/.97-dc23

LC record available at https://lccn.loc.gov/2020045576

Open access edition funded by the National Endowment for the Humanities

A British Cataloging-in-Publication record for this book is available from the British Library.

Copyright $\left({ }^{\circ} 2021\right.$ by Anna I. Corwin

The text of this book is licensed under a Creative Commons Attribution Non Commercial-

No Derivatives 4.o International License: https://creativecommons.org/licenses/

by-nc-nd/4.o/

No part of this book may be reproduced or utilized in any form or by any means, electronic or mechanical, or by any information storage and retrieval system, without written permission from the publisher. Please contact Rutgers University Press, 106 Somerset Street, New Brunswick, NJ 0890 I. The only exception to this prohibition is "fair use" as defined by U.S. copyright law.

The paper used in this publication meets the requirements of the American National Standard for Information Sciences-Permanence of Paper for Printed Library Materials, ANSI Z 39.48-1992.

www.rutgersuniversitypress.org

Manufactured in the United States of America 
For my grandmothers 
